\title{
REPRODUCTIVE BIOLOGY OF KLEIN'S SOLE, SYNAPTURICHTHYS KLEINII (ACTINOPTERYGII: PLEURONECTIFORMES: SOLEIDAE), OFF TUNISIAN COAST (CENTRAL MEDITERRANEAN)
}

\author{
Zouhour BOUAIN *, Lobna BOUDAYA, Abderrahmen BOUAIN, and Lassad NEIFAR \\ Laboratoire de Biodiversité et Ecosystèmes Aquatiques, Faculté des Sciences de Sfax, Université de Sfax, Sfax, Tunisia
}
Bouain Z., Boudaya L., Bouain A., Neifar L. 2018. Reproductive biology of Klein's sole, Synapturichthys kleinii (Actinopterygii: Pleuronectiformes: Soleidae), off Tunisian coast (central Mediterranean). Acta Ichthyol. Piscat. 48 (1): 61-69.

\begin{abstract}
Background. Klein's sole, Synapturichthys kleinii (Risso, 1827), is a rare fish, included in the IUCN Red List as Data Deficient, and its biology is poorly known. Biological investigations of $S$. kleinii have been surprisingly rare in Tunisian waters. In the presently reported study, we investigated the reproductive period, size at first sexual maturity, and fecundity of S. kleinii along the Tunisian waters, with the aim of achieving the first complete and comprehensive description of the reproduction of this fish in the Mediterranean Sea.

Materials and methods. A total of 294 specimens of S. kleinii were sampled over two years, off the Tunisian coasts. Sex ratio was estimated through the seasons of the year and the size classes. The stage of maturity was determined macroscopically only for females. Monthly gonadosomatic index (GSI), monthly hepatosomatic index (HSI), and condition factor $(K)$ were calculated for males and females of $S$. kleinii. Size at first maturity was estimated only for females during the spawning season. Eighteen mature females at spawning stage were collected, weighed, and fixed in $4 \%$ formaldehyde solution for fecundity estimation.

Results. Annual sex ratio showed significant differences between males and females. In specimens exceeding $27 \mathrm{~cm}$ in total length females outnumbered males significantly. The Klein's sole reproduction period started in October and ended in January. The gonadosomatic index reached highest values in November for females and males. Females attained sexual maturity at $20.53 \mathrm{~cm}$ total body length (TL). Total fecundity ranged from 3647 to 23174 eggs. We found a low correlation coefficient between total fecundity and total length, but a high correlation coefficient between eviscerated weight and ovary weight.

Conclusion. Our results constitute a preliminary baseline for monitoring changes in the biological indexes linked to the reproduction cycle and length at first sexual maturity of S. kleinii. The presently acquired data will enable biologists to assess the status of this fish and develop culture technology in natural waters and will be useful for the fishery biologists and conservation biologists, for successful development, management, production, and ultimate conservation of this favoured Tunisian food fish.
\end{abstract}

Keywords: Mediterranean coast, Klein's sole, Synapturichthys kleinii, reproductive biology

\section{INTRODUCTION}

Soleid species occur along the Tunisian coasts and are among the most commercially demanded and expensive food fish in Tunisia, with an estimated annual production of $486 \mathrm{t}$ per year (Anonymous 2014). However, the available statistical data Anonymous (2014) only cover the family Soleidae as a whole. Among those, Klein's sole, Synapturichthys kleinii (Risso, 1827), is a rare species (Cabral 2002, Dallavalle and Chanet 2009, Tous et al. 2015) present in the eastern Atlantic, the Mediterranean Sea and the western Indian Ocean (Heemstra and Gon 1986). It lives in shallow waters, at depths of between 20 and $200 \mathrm{~m}$ (Heemstra and Gon 1986, Quéro et al. 1986) and is captured as bycatch and generally marketed with other soles such as Solea aegyptiaca Chabanaud, 1927 and Solea senegalensis Kaup, 1858, which are the most common soleid species in Tunisia. The Klein's sole is included in the IUCN Red List as Data Deficient. Given its scarcity and shallow water habitat, it is certainly impacted by habitat loss and non-targeted fishing pressure (Tous et al. 2015). It is therefore important and therefore we believe that the biology of this species should be better known.

The conservation status of Mediterranean marine fishes has been assessed using the IUCN Red List Categories and Criteria (Abdul Malak et al. 2011). This assessment was carried out during the course of two workshops, the first held in Istanbul (Turkey) in November 2007, and the second in Sète (France) in February 2008, as well as through 
correspondence with the relevant experts. It highlights the substantial lack of information on the conservation status of nearly one-third of these Mediterranean marine fishes, which were categorised as Data Deficient. Studying red list species would be useful for fishery biologists or fishery decision makers to impose adequate regulations for sustainable fishery management.

Biological investigations of Synapturichthys kleinii living in the Mediterranean Sea have been surprisingly rare. Results of the first biological study of S. kleinii in the Mediterranean Sea was published by Cau and Deiana (1983), with brief information on the reproduction of this fish in Sardinian waters (central-western Mediterranean). Some other studies focused on the biometry of $S$. kleinii found off the coast of Syria (Ali et al. 2015) and parasitology in Corsica (Bartoli et al. 2001), Tunisia (Derbel et al. 2007), and Portugal (Marques et al. 2009, 2011).

In the presently reported study, we investigated the reproductive period, size at first sexual maturity, and fecundity of Synapturichthys kleinii off the Tunisian coasts, with the aim of obtaining a comprehensive description on the reproductive cycle of this fish in the Mediterranean Sea. This information constitutes an important basis for understanding population dynamics and sustainable fisheries.

\section{MATERIALS AND METHODS}

A total of 294 specimens of Synapturichthys kleinii were randomly sampled within two years, from April 2014 through March 2016, at four fishing localities along the Tunisian coasts: Beni Khiar, Sayeda, Sfax, and Zarzis (Fig. 1, Table 1). Specimens were collected by bottom trawlers operating off the eastern Tunisian coast at depths between 30 and $200 \mathrm{~m}$. However, catches were lower during August and September as this period corresponds to the biological rest season in the Gulf of Gabès, during which trawling is forbidden for months.

Samples were brought fresh to the laboratory and total length (TL) to the nearest $0.1 \mathrm{~cm}$, eviscerated weight $\left(W_{\mathrm{e}}\right)$, liver weight $\left(W_{1}\right)$, and gonad weight $\left(W_{\mathrm{g}}\right)$ to the nearest $0.01 \mathrm{~g}$ were recorded for each specimen.

To determine the sex ratio of Synapturichthys kleinii, the gonad was examined macroscopically according to Fishelson and Galil (2001). Sex ratio was estimated across seasons and size classes. Departures from the $1 \div 1$ ratio were tested by $\chi^{2}$ test, with one degree of freedom

Table 1

Sampling sites of Synapturichthys kleinii collected for this study in Tunisian coastal waters

\begin{tabular}{clcc}
\hline No. & \multicolumn{1}{c}{ Site } & Coordinates & $n$ \\
\hline 1 & Beni Khiar & $36^{\circ} 28^{\prime} 01^{\prime \prime} \mathrm{N}, 11^{\circ} 55^{\prime} 09^{\prime \prime} \mathrm{E}$ & 66 \\
2 & Sayeda & $35^{\circ} 40^{\prime} 7^{\prime \prime} \mathrm{N}, 10^{\circ} 53^{\prime} 32^{\prime \prime} \mathrm{E}$ & 83 \\
3 & Sfax & $34^{\circ} 44^{\prime} 26^{\prime \prime} \mathrm{N}, 10^{\circ} 45^{\prime} 37^{\prime \prime} \mathrm{E}$ & 118 \\
4 & Zarzis & $33^{\circ} 30^{\prime} 14^{\prime \prime} \mathrm{N}, 11^{\circ} 06^{\prime} 43^{\prime \prime} \mathrm{E}$ & 27 \\
& & & 294 \\
\hline
\end{tabular}

$n=$ number of fish collected at the level $\alpha=0.05$. The maturity stage was determined macroscopically on the basis of colour, aspect of oocytes, and shape of the ovary, as well as its size in relation to the body cavity. Five stages were identified (Table 2) according to a modified sexual maturity scale proposed by Vallisneri et al. (2001), Afonso-Dias (2005), and Ahmed et al. (2010) for different species of Soleidae. For males, the maturity stages and the size at first maturity were difficult to identify because testes did not display an important macroscopic development like the ovaries.

In order to evaluate the gonadal development during the annual sexual cycle and to determine the spawning season, the monthly gonadosomatic index (GSI) was calculated for males and females, as follows:

$$
\mathrm{GSI}=100 W_{\mathrm{g}} \cdot W_{\mathrm{e}}^{-1}
$$

The monthly hepatosomatic index (HSI) and condition factor $(K)$ were also calculated for each sex, as follows:

$$
\begin{gathered}
\mathrm{HSI}=100 W_{1} \cdot W_{\mathrm{e}}^{-1} \\
K=100000 W_{\mathrm{e}} \cdot \mathrm{TL}^{-3}
\end{gathered}
$$

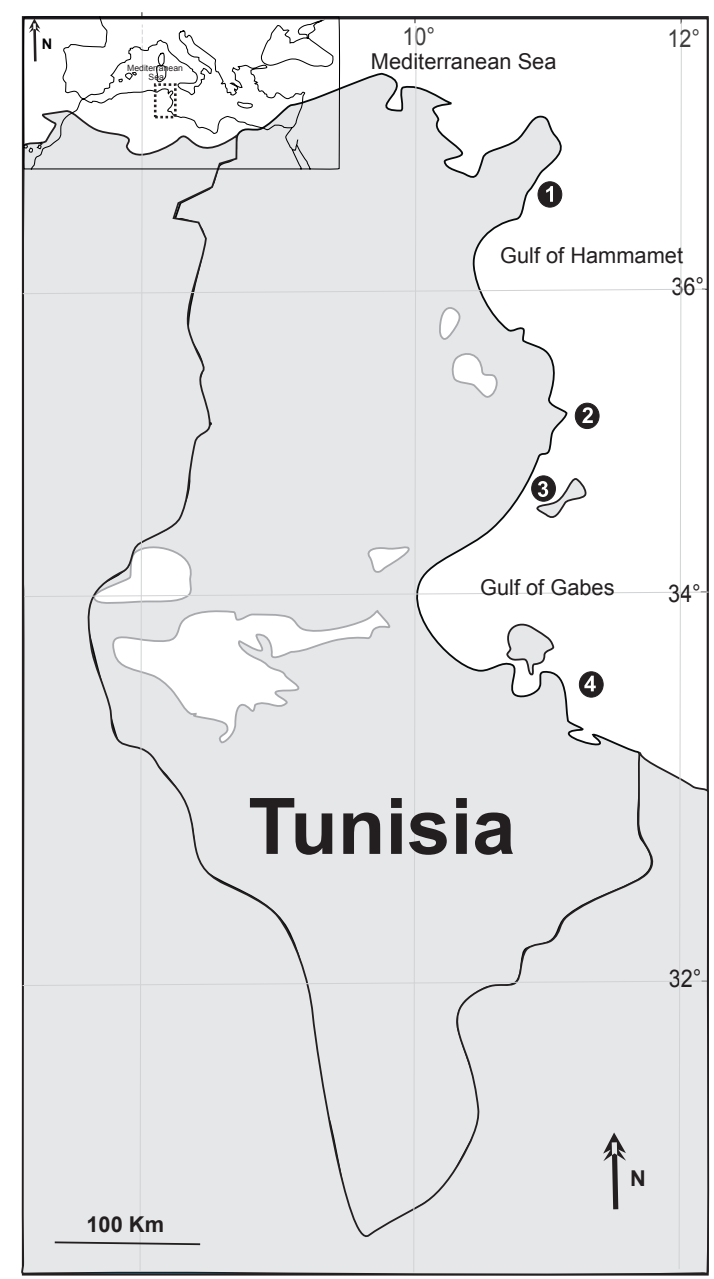

Fig. 1. Sampling sites (1-4) of Synapturichthys kleinii along the Tunisian coast in the central Mediterranean Sea (inset above); site details are provide in Table 1 
Monthly values of all indices were compared using a one-way ANOVA test (Dagnélie 1970). The results are presented as the mean ( \pm standard error), and the significance level used for the tests was $P<0.05$.

The size at first maturity was estimated only for females during the spawning season for the mature specimens in stages III, IV, and V. This is defined as the total length at which $50 \%$ of females are mature and was estimated by means of a logistic function fitted to the proportion of the mature specimens grouped in $1 \mathrm{~cm}$ length class (TL). To estimate the size at first sexual maturity $\mathrm{TL}_{50}$, we calculated the proportion $\left(P_{i}\right)$ of mature individuals by sex and by size class:

$$
P_{i}=100 M_{i} \cdot N_{i}^{-1}
$$

where $M_{i}$ is the number of mature individuals in the size class and $N_{i}$ is the number of examined individuals in the same size class $i$. The data were fitted to a logistical function by using the software FISHPARM*. The proportion of mature fish at size TL was calculated using the equation:

$$
\left(1+\mathrm{e}^{-\left(\mathrm{TL}-\mathrm{TL}_{50}\right)}\right)^{-1}
$$

which is the curvature parameter (King 2007). This function allows the estimation with precision the lengths $\mathrm{TL}_{25}, \mathrm{TL}_{50}$, and $\mathrm{TL}_{75}$ that are often required by the majority of fisheries science software to carry out fish stock assessments (Pauly 1980, Ghorbel et al. 1996).

Table 2

Macroscopic scale of female gonads of Synapturichthys

\begin{tabular}{|c|c|}
\hline Stage & Description \\
\hline $\begin{array}{l}\text { Stage I: Immature or } \\
\text { resting }\end{array}$ & $\begin{array}{l}\text { Ovaries consist of two thin } \\
\text { colourless parallel filaments; no } \\
\text { oocytes visible }\end{array}$ \\
\hline Stage II: Developing & $\begin{array}{l}\text { Ovaries increase in length and } \\
\text { width becoming opaque, white- } \\
\text { pinkish; no oocytes visible }\end{array}$ \\
\hline Stage III: Maturing & $\begin{array}{l}\text { Ovaries increase considerably } \\
\text { in volume occupying half of } \\
\text { visceral cavity, appearing to be } \\
2-3 \mathrm{~mm} \text { thick, yellow-orange } \\
\text { with small oocytes visible under } \\
\text { stereomicroscope }\end{array}$ \\
\hline Stage IV: Spawning & $\begin{array}{l}\text { Ovaries occupying almost entire } \\
\text { peritoneal cavity, orange, with } \\
\text { evident hydrated oocytes, which } \\
\text { are extruded copiously under } \\
\text { light pressure }\end{array}$ \\
\hline $\begin{array}{l}\text { Stage V: Post- } \\
\text { spawning }\end{array}$ & $\begin{array}{l}\text { Ovaries are empty or partially } \\
\text { empty, flaccid and reddish with } \\
\text { predominantly opaque oocytes }\end{array}$ \\
\hline
\end{tabular}
kleinii
Total fecundity was estimated for 18 mature females of Synapturichthys kleinii at spawning stage. The ovaries were collected, weighed, and fixed in $4 \%$ formaldehyde solution for fecundity estimation. After 3 months, each sample was carefully washed with running water. Three subsamples weighing between $8 \%$ and $12 \%$ of the total gonad weight were taken separately from the anterior, middle, and posterior regions of each ovary. Oocytes were separated from ovarian tissues by means of a teasing needle and their diameters were measured using an eye-piece micrometre on the stereomicroscope. We have therefore taken into account the oocytes which are not completely ripe, but which were in vitellogenesis with a compact cytoplasm, and are thus liable to be spawned in the season of reproduction. The mean diameter of oocytes was determined by the results of measurements of 798 oocytes from 3 subsamples. In fact, oocyte diameter provides a measure for determining whether the fish spawned once or several times in a breeding season (Ahmed et al. 2010).

The relative fecundity, that is the total number of eggs per unit of total length, eviscerated weight, and gonads weight were estimated by applying regression equation (Bagenal 1971)

$$
F=a X^{b}
$$

where $F$ is the fecundity, $X$ is an independent variable, and $a$ and $b$ were estimated by using the multiplicative regression model.

\section{RESULTS}

Sex ratio. Among the 294 specimens examined during the study period, 166 were females $(56.46 \%)$ and 128 were males (43.53\%). Body length of the females in the catches ranged from 17.3 to $30 \mathrm{~cm}$ with the mean $( \pm \mathrm{SD}$ ) assuming the value $24.3 \pm 2.51 \mathrm{~cm}$. Body length of the males was $19.6-27.7 \mathrm{~cm}$, with the mean $( \pm \mathrm{SD})$ of $23.1 \pm 2.75 \mathrm{~cm}$ (Table 3$)$.

The overall sex ratio was $1.29 \div 1$ which is statistically significantly different from $1 \div 1\left(\chi^{2}=4.91, \alpha<0.05\right)$; in any case, females almost predominated over males. The seasonal variations in the sex ratio of Klein's sole did not vary significantly throughout the year except in autumn $\left(\chi^{2}=6.26, \alpha<0.05\right)$ where it reached $1.75 \div 1$ in favour of females (Fig. 2).

The size variations in the sex ratio of Klein's sole did not vary significantly in size classes $<27 \mathrm{~cm}\left(0.02<\chi^{2}<3.45\right.$, $\alpha>0.05)$. Noticeably, females predominated males for fishes larger than this size, with $4.80<\chi^{2}<7.54, \alpha<0.05$ (Fig. 3).

Monthly variations in maturity stages. When the gonads are small and outside the spawning season, a squash mount technique was performed to determine the sex. Monthly variations in the sexual maturity of females of Synapturichthys kleinii are provided in Fig. 4. Immature females (stage I) were found throughout the year $(n=$ 46). Developing ovaries (Stage II) started to be visible in February through September $(n=26)$. Maturing ovaries (stage III) appeared in March through October $(n=18)$. Mature females in stage IV were found in October through 
January $(n=54)$. Females in stage $\mathrm{V}$ were caught from November through February $(n=22)$.

Sexual cycle. Monthly fluctuations of gonadosomatic index (GSI) values of Synapturichthys kleinii are illustrated in Fig. 5. The percentage of females in each developmental stage in each month is consistent with the variation pattern obtained for the GSI (Fig. 5A). GSI values were low from February to June (less than 1.5). GSI increased by the end of June and reached the highest values in autumn from October to January, with a maximum obtained in November $(\mathrm{GSI}=5.28)$, which was the period when the highest percentage of individuals in stage IV (spawning) was recorded. The differences of GSI during the sampled months were highly significant $(\mathrm{ANOVA}=15.27, P<0.05)$.

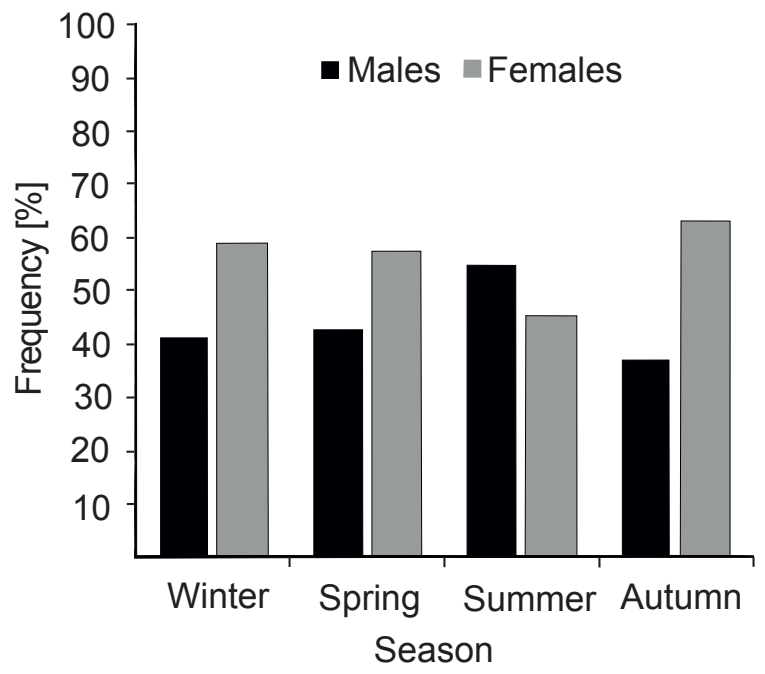

Fig. 2. Seasonal frequency distribution of Synapturichthys kleinii sampled along the Tunisian coast: females, $n=166$; males, $n=128$
Males showed a similar trend with the highest values of GSI in October to November and the lowest from February to June (Fig. 5B). The differences in GSI during the sampled months were highly significant (ANOVA $=3.24, P<0.05)$. Noticeably, the values obtained for females (mean value from 1.25 to 5.28) were much higher than those determined for males (mean value from 0.09 to 0.27 ).

In females, the hepatosomatic index (HIS) had the highest values during the post-spawning and development period, with a marked decrease in the reproductive period (Fig. 6A). In males, the HSI values exhibited a similar trend (Fig. 6B). The differences of HSI during the sampled months were highly significant for both sexes (female: $\mathrm{ANOVA}=6.27, P<0.05$; male $\mathrm{ANOVA}=3.24, P<0.05$ ).

The condition factor $(K)$ indicated the same trend as the HSI in both sexes. However, it presented a significant

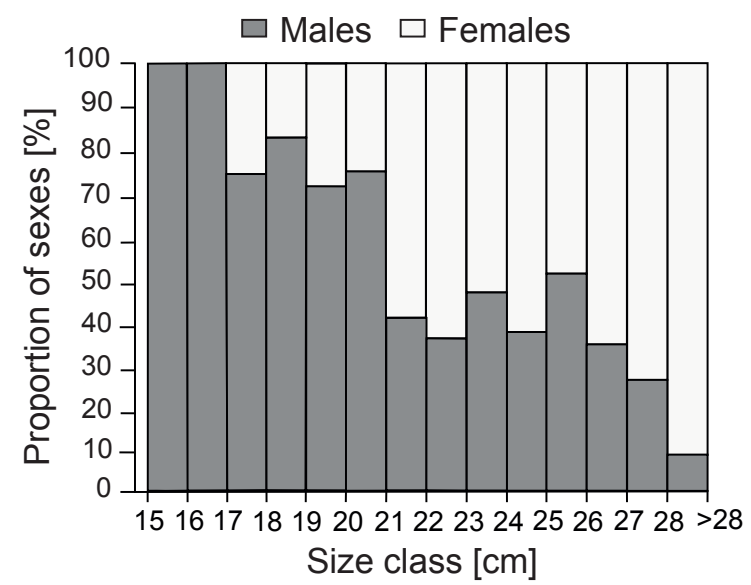

Fig. 3. Body length frequency distribution of Synapturichthys kleinii sampled along the Tunisian coast: females, $n=166$ males, $n=128$

Table 3

Basic biological and morphometric data of Synapturichthys kleinii collected in Tunisian marine coastal waters during presently reported study

\begin{tabular}{clcccc}
\hline \multirow{2}{*}{ Season } & \multicolumn{2}{c}{ Month } & \multicolumn{2}{c}{ Number of fish } & \multicolumn{2}{c}{ Total length range [cm] } \\
\cline { 3 - 6 } & & Females & Males & Females & Males \\
\hline \multirow{2}{*}{ Winter } & December & 27 & 16 & $18.4-28.3$ & $17.0-27.0$ \\
& January & 5 & 5 & $23.5-25.5$ & $20.5-24.6$ \\
& February & 15 & 12 & $18.1-28.5$ & $19.6-26.0$ \\
\multirow{5}{*}{ Spring } & March & 9 & 7 & $21.7-29.0$ & $15.5-25.6$ \\
& April & 9 & 7 & $18.5-26.5$ & $23.5-26.8$ \\
& May & 10 & 7 & $22.0-28.0$ & $17.4-25.4$ \\
& June & 18 & 17 & $18.7-28.7$ & $19.3-27.2$ \\
& July & 11 & 19 & $17.3-30.0$ & $21.3-28.6$ \\
& August & 4 & 4 & $27.0-28.0$ & $21.0-26.2$ \\
& September & 5 & 3 & $21.3-25.0$ & $17.8-24.0$ \\
& October & 12 & 9 & $18.0-27.5$ & $18.0-27.5$ \\
& November & 41 & 22 & $20.5-29.3$ & $19.6-27.7$ \\
& Total & 166 & 128 & $17.3-30.0$ & $15.5-28.6$ \\
\hline
\end{tabular}


monthly variation for both sexes (female ANOVA $=6.00$, $P<0.05$; male ANOVA $=7.05, P<0.05)$. It ranged from 0.64 to 0.83 for females (Fig. 6A) and 0.66 to 0.88 for males (Fig. 6B).

Size at first sexual maturity. The percentage of mature females of Synapturichthys kleinii in each length class of $1 \mathrm{~cm}$ interval is plotted in Fig. 7. The female's length at first maturity $\mathrm{TL}_{50}$ was estimated at $20.53 \mathrm{~cm}\left(R^{2}=0.989\right)$, and $\mathrm{TL}_{25}$ and $\mathrm{TL}_{75}$ were respectively 19.96 and $21.03 \mathrm{~cm}$. However, the smallest mature female was $19.5 \mathrm{~cm}$.

Fecundity. Two oocyte categories were observed in ovaries: the first one displayed a transparent cytoplasm,

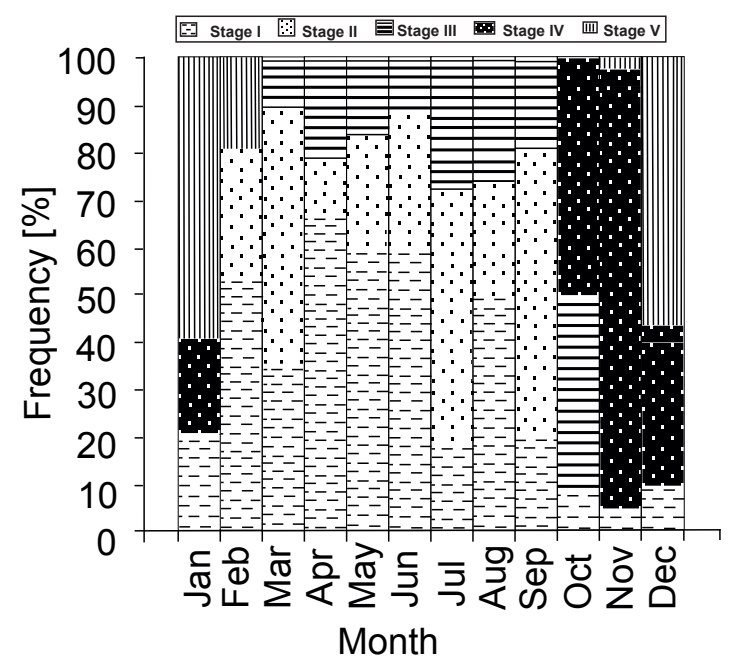

Fig. 4. Monthly variations of sexual maturity stage of females of Synapturichthys kleinii sampled along the Tunisian coast

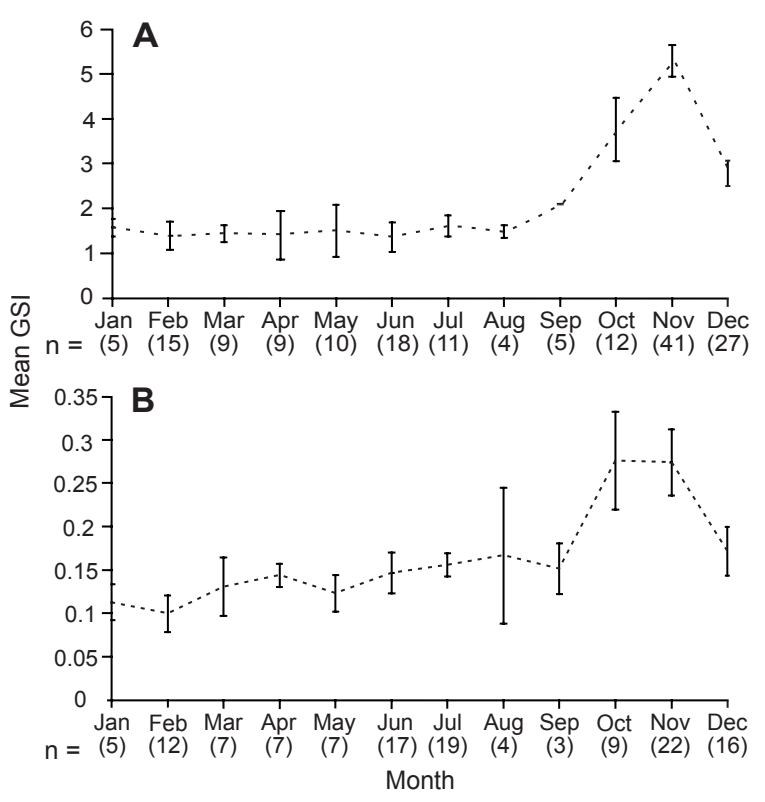

Fig. 5. Monthly variations of gonadosomatic index (GSI) of females (A) and males (B) of Synapturichthys kleinii, sampled along the Tunisian coast having not started vitellogenesis, with a diameter strictly $<$ $700 \mu \mathrm{m}$. The second one included oocytes with a compact cytoplasm, having accomplished vitellogenesis, with a diameter $\geq 700 \mu \mathrm{m}$. However, those with a diameter $=$ $700 \mu \mathrm{m}$ contain $40 \%$ yolked and $60 \%$ unyolked oocytes. Yolked oocytes having a diameter of between $700 \mu \mathrm{m}$ and $1260 \mu \mathrm{m}$ were counted and their mean diameter was found to be $900 \mu \mathrm{m}( \pm 63.9)$. The frequency distributions of oocyte diameters show two peaks at 900 and $1200 \mu \mathrm{m}$, indicating an asynchronous oocyte organization (Fig. 8).

Total fecundity ranged from 3647 to 23174 oocytes with a mean number of $9509 \pm 1139$ oocytes. For the

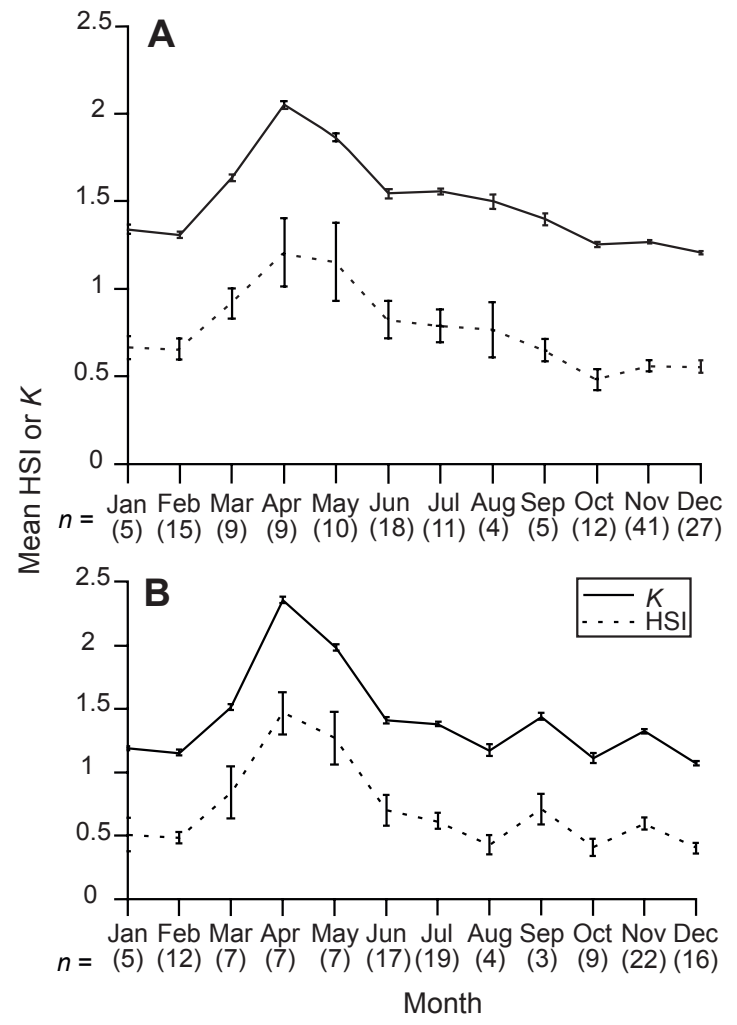

Fig. 6. Monthly variations of hepatosomatic index and condition factor $(K)$ of females $(\mathbf{A})$ and males $(\mathbf{B})$ of Synapturichthys kleinii sampled along the Tunisian coast

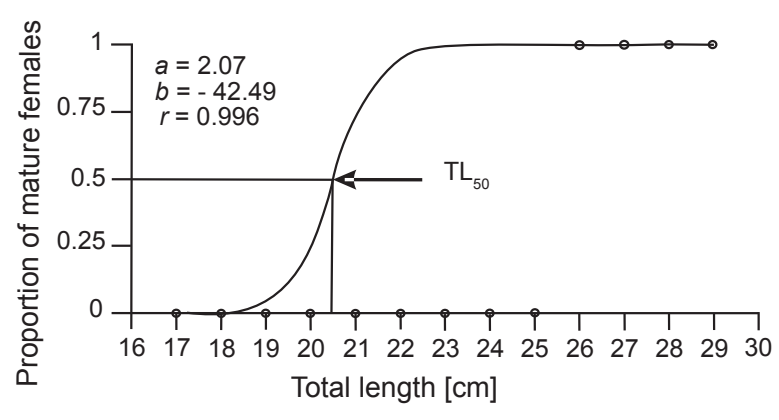

Fig. 7. Length at first maturity of females of Synapturichthys kleinii sampled along the Tunisian coast $(n=73)$ 
relative fecundity, the number of oocytes per length varied between 162 and 842 with a mean of $376 \pm 41.5$ oocytes per $1 \mathrm{~cm}$ length. It ranged between 43 and 133 with a mean of $82 \pm 6.4$ per gram of eviscerated weight. It also varied between 700 and 2021 with a mean of $1290 \pm 89.2$ oocytes per gram of gonad weight. Plots of fecundity versus total length (Fig. 9A), eviscerated weight (Fig. 9B) and gonad weight (Fig. 9C) indicated a regression model.

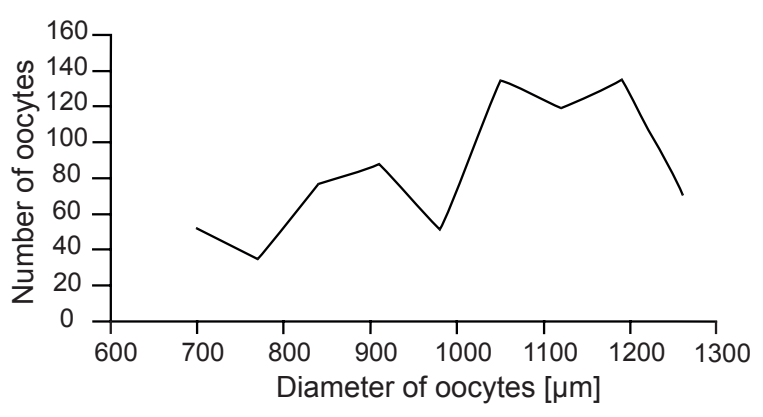

Fig. 8. Frequency distributions of oocytes diameters in the spawning period of Synapturichthys kleinii sampled along the Tunisian coast $(n=763)$
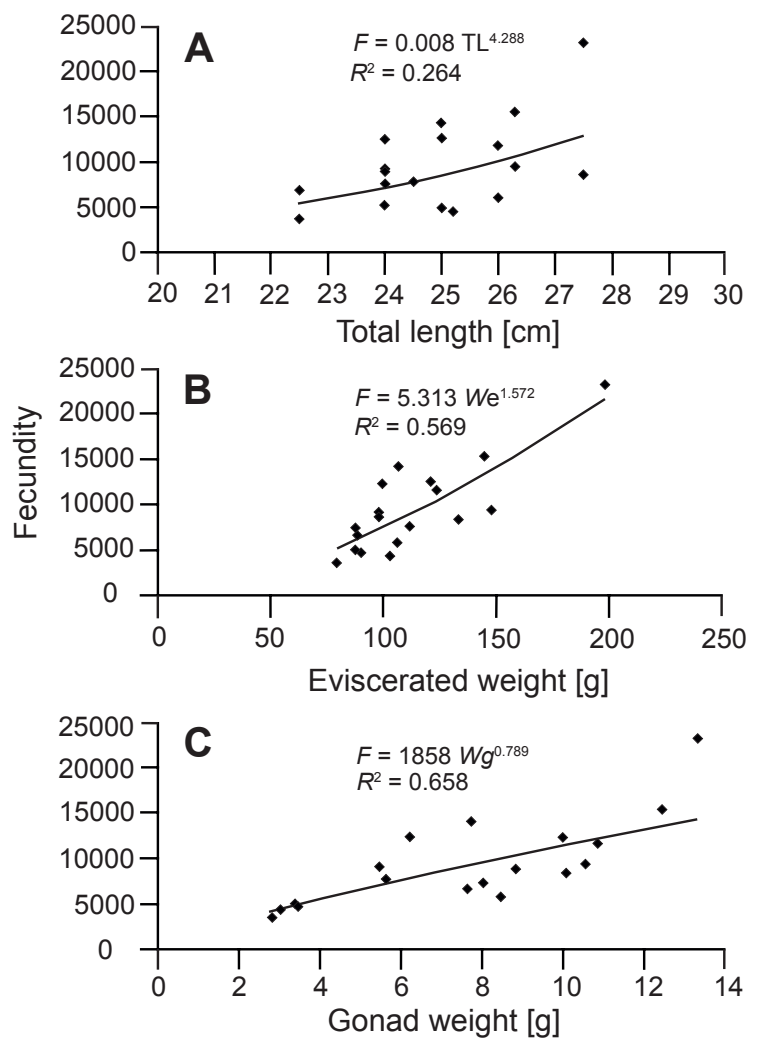

Fig. 9. Basic biometric relations of Synapturichthys kleinii sampled along the Tunisian coast: relation between the fecundity and the total length $(\mathbf{A})$, relation between the fecundity and the eviscerated weight $\left(W_{\mathrm{e}}\right)(\mathbf{B})$, relation between the fecundity and the gonads weight $\left(W_{\mathrm{g}}\right)(\mathbf{C})$

\section{DISCUSSION}

This paper represents the second investigation regarding the reproductive biology of Synapturichthys kleinii in the Mediterranean Sea after the study of Cau and Deiana (1983) in Sardinian waters.

Sex ratio is an important indicator of population state and the sustainability of species (Kartas and Quignard 1984). This ratio is generally close to $1 \div 1$ for the majority of species (Nikolski 1963). However, our study revealed that this ratio differs significantly for Synapturichthys kleinii. Its seasonal variations show a significant difference only in autumn. This difference was probably related to their reproductive biology. Accordingly, this period corresponds to the peak of reproductive activity. The departure of sex ratio from unity $(1 \div 1)$ can be the result of several factors, such as partial segregation of mature forms through habitat preference (Ahmed et al. 2010) or due to differential migration and/or other behavioural differences between sexes, rendering one sex more likely to be caught than the other (Mehanna 2014). This could also be explained by a polygenic mating system (one male choosing to mate with two or more females) (Farias et al. 2015).

The size difference between the sexes can be explained by the differential growth rate of the adults between the two sexes, with females attaining larger sizes than males (Andrade 1998). The difference in growth between the sexes may be caused by a distinct difference in metabolism between the two sexes (Pauly 1994). This difference could also be attributed to differential mortality, either natural or as a result of trawling (Mehanna 2014).

Macroscopic investigation of female gonads revealed the presence of five stages of ovary development that characterize the sexual cycle of Synapturichthys kleinii off the Tunisian coasts. Monthly variations in the maturity stages of Synapturichthys kleinii confirmed that the spawning season of this species extends from October to January. Cau and Deiana (1983) concluded that the spawning season of $S$. kleinii from Sardinian waters extended only from October to November in contrast to our finding that the species is an autumn/winter spawner in Tunisian waters. Our results are consistent with the findings of many other researchers who worked on flatfishes and the common conclusion was that flatfishes are generally winter spawners (Zaki and Hamza 1986, Valllisneri et al. 2001, Ahmed et al. 2010). Such differences in the spawning period of this species could indicate the role of environmental conditions in the timing of their reproductive cycle (Baggerman 1980, Wootton 1982, 1984, Bye 1984, Jiménez et al. 1998). The asynchrony in the spawning between old and young females could explain the extended spawning season in Tunisian coasts. For example, females in October, which is the spawning period (Stage IV), with TL $>25 \mathrm{~cm}$ represent $65 \%$ and those with $\mathrm{TL}<25 \mathrm{~cm}$ represent $35 \%$. In November, these two percentages are switched. This result confirms that the younger females spawn later than the older ones.

Analysis of GSI indexes are in agreement with the percentage of individuals in each developmental stage. 
The highest values of GSI were obtained in autumn, which was the period when the highest percentage of females at stage IV was recorded (49\%: mean percentage of females during the spawning period). Comparing GSI of males and females, it can be seen that the values obtained for females (mean value from 1.35 to 5.28) were much higher than those determined for males (mean value from 0.09 to 0.27 ). A significant decrease in the mean GSI of males and females indicated the post-spawning and the sexual rest.

The hepatosomatic index and the condition factor presented the same trend during the sexual cycle. These two indexes decrease during the spawning period and reach a minimum when the GSI in maximum. This indicates that this fish probably stocks its energy reserves in liver and muscle. Such reserves might be sequentially transferred to the ovary for gonad maturation and to be used for the energetic requirements of spawning

The presently reported study is the first attempt to determine the size at first maturity of Synapturichthys kleinii from the central Mediterranean Sea. The size at sexual maturity is an important indicator in fishery management and legal catch size (Lucifora et al. 1999, Wang et al. 2003). Off the Tunisian coasts, Klein's sole females mature at 20.53 $\mathrm{cm}$ of total body length. This value is lower than that found for the same species living off the Sardinian coast $\mathrm{TL}_{50}$ ㅇ $=29 \mathrm{~cm}$ (Cau and Deiana 1983). This size corresponds to practically the maximum size that we have observed for this species along the Tunisian coasts $\mathrm{TL}_{\max }=30 \mathrm{~cm}$. Given that the data of Cau and Deiana (1983) recorded in the Sardinian waters are quite old, it is possible that the strategy of S. kleinii has changed for this area as found by Porcu et al. (2010) for Bathypterois dubius Vaillant, 1888. Indeed, the length at first sexual maturity varies greatly from one species to another and within the same species. The difference of $\mathrm{TL}_{50}$ from one area to another could be due to an increase in fishing pressure (Hard et al. 2008, Lappalainen et al. 2016), which can lead to moderation in growth and a decrease in maturation size (Mcphail et al. 2001). In fact, the Gulf of Gabès suffers from overfishing, which may decrease the size at first sexual maturity of S. kleinii in this area and may extend its reproduction period (Bradai unpublished*).

The frequency distributions of oocyte diameter (stage IV) indicate that spawning occurs in at least two batches. Total fecundity (stage IV) is not strongly related to the total fish length $\left(R^{2}=0.264\right)$. However, it is highly related to the eviscerated weight $\left(R^{2}=0.569\right)$ and gonad weight $\left(R^{2}=\right.$ 0.658) (Fig. 9). The total fecundity of Synapturichthys kleinii females ranged between 3647 and 23174 eggs for lengths between 22.5 and $27.5 \mathrm{~cm}$ respectively. This is considerably lower than that reported for other soleid species.

In fact, the total fecundity of Solea aegyptiaca in Egyptian waters ranged between 9898 and 39505 eggs for lengths between 15.8 and $30.5 \mathrm{~cm}$ respectively (Ahmed et al. 2010). Mehanna (2014) found that the total fecundity of Solea solea ranged between 270000 to 1200000 eggs for lengths between 16 and $33.5 \mathrm{~cm}$ in the Bardawil Lagoon. Variation in fecundity between localities and species can likely be explained by environmental factors and food intake by the individual (Simpson 1951, Bagenal and Tesch 1978) and by biological parameters such as age and size. The variation in fecundity is very common in fish and has been reported by many researchers (Reddy et al. 1991, Bhuiyan et al. 2006). Numerous factors like different stock of fish, nutritional status (Gupta et al. 1967), racial characteristics (Das 1977), time of sampling, maturation stage, and changes in environmental parameters (Reddy et al. 1991) have so far been reported to affect the fecundity both within the species, localities and between fish populations. Reproductive potential of the fishes is also influenced by the availability of space and food (Islam et al. 2012).

In the presently reported work, the relative fecundity of Synapturichthys kleinii varied from 162 to 842 eggs per $\mathrm{cm}$ of total length. To compare with other studies, Ahmed et al. (2010) mentioned that the relative fecundity of Solea aegyptiaca in Mediterranean Egyptian waters ranged from 616 to 1270 eggs per $\mathrm{cm}$. This difference can be explained by the greater growth rate of $S$. aegyptiaca compared with S. kleinii.

\section{CONCLUSION}

This work constitutes a contribution to the knowledge of the reproductive biology of an endangered species of Soleidae included in the IUCN Red List as a Data Deficient. Information on the biology of Synapturichthys kleinii is rare or almost non-existent throughout the world. Our results contribute to a preliminary basis for monitoring the changes in biological indexes linked to the reproduction cycle and length at first sexual maturity of S. kleinii.

This study will help biologists to determine the status of this fish and to develop aquaculture technology in natural waters. Furthermore, this will be useful for fishery and conservation biologists, for the successful development, management, production and ultimate conservation one of the most fish of this region.

\section{ACKNOWLEDGEMENT}

We are grateful to Dr Helen Robertson from the University College London, Professor Michael Paul from the University of Marseille, and Professor Rodney Bray from the Natural History Museum, London for linguistic revision. We sincere thanks to Professor François Bonhomme, Professor Jean-Pierre Quignard from the University of Montpellier, and Dr Wiem Boussellaa for their comments and improvements.

\section{REFERENCES}

Abdul Malak D., Livingstone S.R., Pollard D., Polidoro B.A., Cuttelod A., Bariche M., Bilecenoglu M., Carpenter K.E., Collette B.B., Francour P., Goren M., Kara M.H., Massutí E., Papaconstantinou C., Tunesi L. 2011. Overview of the Conservation Status of the Marine Fishes of the Mediterranean Sea. IUCN, Gland, Switzerland and Malaga, Spain. 
Afonso-Dias I., Reis C., Andrade J.P. 2005. Reproductive aspects of Microchirus azevia (Risso, 1810) (Pisces: Soleidae) from the south coast of Portugal. Scientia Marina 63 (2): 275-283. DOI: 10.3989/scimar.2005.69n2275

Ahmed A.I., Sharaf M.M., Laban H.A. 2010. Reproduction of the Egyptian sole Solea aegyptiaca (Actinopterygii: Pleuronectiformes: Soleidae), from Port Said, Egypt, Mediterranean Sea. Acta Ichthyologica et Piscatoria 40 (2): 161-166. DOI: 10.3750/AIP2010.40.2.09

Ali M., Saad A., Fadel M., Issa I., Capapé C. 2015 First record of Klein's Sole Synapturichthys kleinii (Osteichthyes: Soleidae) off the Syrian coast (Eastern Mediterranean). Journal of Ichthyology 55 (6): 918921. DOI: $10.1134 / \mathrm{S} 0032945215060016$

Andrade J.P. 1998. Age and growth of the bastard sole, Microchirus azevia (Capello, 1868) (Pisces, Soleidae) from the south coast of Portugal. Fisheries Research 34 (2): 205 208. DOI: 10.1016/S0165-7836(97)00093-3

Anonymous 2014. Annuaire des statistiques de pêche de la Direction Générale de la pêche et de l'Aquaculture, Tunis, Tunisie.

Bagenal T.B. 1971. Egg and early life history. Pp. 166199. In: Bagenal T.B., Ricker W.E. (eds.) Methods of assessments of fish production in fresh waters. Blackwell Science Publishers, Oxford, UK.

Bagenal T.B., Tesch F.W. 1978. Age and growth. Pp. 101136. In: Bagenal T.B (ed.) Methods for assessment of fish production in fresh waters. 3rd ed. Blackwell Scientific Publication, Oxford, U.K.

Baggerman B. 1980. Photoperiodic and endogenous control of the annual reproductive cycle in teleost fishes. DOI: 10.1007/978-1-4899-3659-2_21. Pp. 533-567. In: Ali M.A. (ed.) Environmental Physiology of Fishes Vol. 35 of NATO Advanced Study Institutes Series. Series A: Life Sciences. Springer Science + Business Media New York, NY, USA.

Bartoli P., Cribb T.H., Bray R.A. 2001. A redescription of Homalometron senegalense Fischtal and Thomas, 1972 (Digenea: Apocreadidae) from Synaptura kleinii (Teleostei) of the western Mediterranean. Systematic Parasitology 50 (2): 135-141. DOI: 10.1023/A:1011917230199

Bhuiyan A.S., Islam K., Zaman T. 2006. Fecundity and ovarian characteristics of Puntius gonionotus (Bloch/ Bleeker) (Cyprinidae: Cypriniformes). Journal of BioScience 14: 99-102. DOI: 10.3329/jbs.v14i0.451

Bye V. 1984. The role of environmental factors in the timing of reproductive cycles. Pp. 187-205. In: Potts G.W., Wootton R.J. (eds.) Fish reproduction, strategies and tactics. Academic Press, London.

Cabral H.N. 2002. On the occurrence of some rare flatfish species in south-European Atlantic waters. Thalassas 18 (1): 31-38.

Cau A., Deiana A.M. 1983. Reproduction et accroissement dans quelques Soleidae de la Méditerranée du centre occidental. Rapports et Procès-Verbaux des Réunions Commission Internationale pour l'Exploration Scientifique de la Mer Méditerranée 28 (5): 61-62.
Dagnélie P. 1970. Théorie et méthodes statistiques. Applications agronomiques. Presses agronomiques, Gembloux, Belgium.

Dallavalle G., Chanet B. 2009. New data on the biology of Klein's sole Synapturichthys kleinii (Pleuronectiformes: Soleidae). Marine Biodiversity Records 2: e70. DOI: 10.1017/S1755267209000876

Das H.P. 1977. The fecundity of grey mullet, Mugil cephalus L. along Goa coast. Mahasagar 10 (1-2): 63-71.

Derbel H., Boudaya L., Neifar L. 2007. Pseudodiplectanum syrticum n. sp. (Monogenea: Diplectanidae), a parasite of Synapturichthys kleinii (Teleostei: Soleidae) from off Tunisia. Systematic Parasitology 68 (3): 225-231. DOI: 10.1007/s11230007-9108-4

Farias I.P., Leão A., Almeida Y.S., Verba J.T, Crossa M.M., Honczaryk A., Hrbek T. 2015. Evidence of polygamy in the socially monogamous Amazonian fish Arapaima gigas (Schinz, 1822) (Osteoglossiformes, Arapaimidae). Neotropical Ichthyology 13 (1): 195 204. DOI: 10.1590/1982-0224-20140010

Fishelson L., Galil B.S. 2001. Gonad structure and reproductive cycle in the deep-sea hermaphrodite tripodfish Bathypterois mediterraneus (Chlorophthalmidae, Teleostei). Copeia 2001 (2): 556-560. DOI: 10.1643/0045-8511(2001)001[0556:GSARCI] 2.0.CO;2

Ghorbel M., Jarboui O., Bradai M.N., Bouain A. 1996. Détermination de la taille de première maturité sexuelle par une fonction logistique chez Limanda limanda, Pagellus erythrinus et Scorpaena porcus. Bulletin de l'Institut National des Sciences et Technologies de la Mer, Salammbô 23 (Num. Spec. 3): 24-27.

Gupta M.V. 1967. Observation on the fecundity of Polynemus paradism Linn from the Hoogly estuarine system. Proceedings of the National Academy of Sciences, India Section B: Biological Sciences 34: 330-345.

Hard J.J., Gross M.R., Heno M., Hilborn R., Kope R.G., Law R., Reynolds J.D. 2008. Evolutionary consequences of fishing and their implications for salmon. Evolutionary Applications 1 (2): 388-408. DOI: $10.1111 /$ j.1752-4571.2008.00020.x

Heemstra P.C., Gon O. 1986. Soleidae. Pp. 868-874. In: Smith M.M., Heemstra P.C. (eds.) Smiths' sea fishes. Springer-Verlag, Berlin, Germany. DOI: 10.1007/9783-642-82858-4

Islam M.R., Sultana N., Belal Hossain M., Mondal S. 2012. Estimation of fecundity and gonadosomatic index (GSI) of Gangetic whiting, Sillaginopsis panijus (Hamilton, 1822) from the Meghna River estuary, Bangladesh. World Applied Sciences Journal 17 (10): 1253-1260.

Jiménez M.P., Sobrino I., Ramos F. 1998. Distribution pattern, reproductive biology, and fishery of the wedge sole Dicologlossa cuneata in the Gulf of Cadiz, south-west Spain. Marine Biology 131 (1): 173-187. DOI: $10.1007 / \mathrm{s} 002270050308$ 
Kartas F., Quignard J.P. 1984. La fécondité des poissons Téléostéens. Collection de biologie des milieux marins, Paris, France.

King M.G. 2007. Fisheries biology, assessment and management. 2nd edn. Fishing New Books. Blackwell Publishing, Oxford, UK.

Lappalainen A., Saks L., Šuštar M., Heikinheimo O., Jürgens K., Kokkonen E., Kurkilahti M., Verliin A., Vetemaa M. 2016. Length at maturity as a potential indicator of fishing pressure effects on coastal pikeperch (Sander lucioperca) stocks in the northern Baltic Sea. Fisheries Research 174: 47-57. DOI: 10.1016/j.fishres.2015.08.013

Lucifora L.O., Valero J.L., García V.B. 1999. Length at maturity of the greeneye spurdog shark, Squalus mitsukurii (Elasmobranchii: Squalidae), from the SW Atlantic, with comparisons with other regions. Marine and Freshwater Research 50 (7): 629-632. DOI: $10.1071 /$ MF98167

Marques J.F., Santos M.J., Cabral H.N. 2009. Zoogeographicalpatternsofflatfish(Pleuronectiformes) parasites in the northeast Atlantic and the importance of the Portuguese coast as a transitional area. Scientia Marina 73 (3): 461-471. DOI: 10.3989/ scimar.2009.73n3461

Marques J.F., Santos M.J., Teixeira C.M., Batista M.I., Cabral H.N. 2011. Host-parasite relationships in flatfish (Pleuronectiformes) - the relative importance of host biology, ecology and phylogeny. Parasitology 138 (1): 107-121. DOI: 10.1017/S0031182010001009

Mcphail A.S., Shipton T.A., Sauer W.H.H., Leslie R.W. 2001. Aspect of the biology of cape gurnard, Chelidonichthys capensis (Scorpaeniformes: Triglidae) on the Agulhas Bank, South Africa. Vie et Milieu 51 (4): 217-227.

Mehanna S.F. 2014. Reproductive dynamics of the common sole Solea solea (Linnaeus, 1758) from Bardawill lagoon, North Sinai, Egypt. Tropentag 2014, 17-19 September 2014. Conference on International Research on Food Security, Natural Resource Management and Rural Development. Czech University of Life Sciences, Prague, Czech Republic. http://www.tropentag.de/2014/abstracts/full/611.pdf

Nikolski G.V. 1963. The ecology of fishes. Academic Press, London, UK.

Pauly D. 1980. A selection of simple methods for assessment of tropical fish stocks. FAO Fisheries Circular 729: 1-54.
Pauly D. 1994. On the sex of fish and the gender of scientists. Essays in fisheries science, London, UK.

Porcu C., Follesa M.C., Grazioli E., Deiana A.M., Cau A. 2010. Reproductive biology of a bathyal hermaphrodite fish, Bathypterois mediterraneus (Osteichthyes: Ipnopidae) from the south-eastern Sardinian Sea (central-western Mediterranean). Journal of the Marine Biological Association of the United Kingdom 90 (4): 719-728. DOI: 10.1017/ S0025315409991330

Quéro J.C., Desoutter M., Lagardère F. 1986. Soleidae. Pp. 1308-1324. In: Whitehead P.J.P., Bauchot M.-L., Hureau J.-C., Nielsen J., Tortonese E. (eds.) Fishes of the North-eastern Atlantic and Mediterranean. Vol. 1. UNESCO, Paris.

Reddy Y.S., Rao M.B. 1991. Gonadosomatic index and fecundity of Heteropneustes fossilis (Bloch) (Pisces: Heteropneustidae) from Hussain Sagar, Hyderabad. Indian Journal of Fisheries 38 (2): 93-96.

Simpson A.C. 1951. The fecundity of the plaice. Fishery Investigations London Series 2, 17 (5): 1-27.

Tous P., Sidibe A., Mbye E., Djiman R., Camara Y.H., Adeofe T.A., Monroe T., Camara K., Cissoko K., de Morais L., Sagna A., Sylla M. 2015. Synapturichthys kleinii. The IUCN Red List of Threatened Species 2015: e.T198740A15595742. DOI: $10.2305 / \mathrm{IUCN}$. UK.2015-4.RLTS.T198740A15595742.en

Vallisneri M., Tinti F., Tommasini S., Piccinetti C. 2001. Reproductive cycle of the common sole Solea vulgaris Quensel, 1806 in the northern Adriatic Sea. Acta Adriatica 42 (2): 59-63.

Wang S.P., Su C.L., Yeh S.Z. 2003. Sex ratios and sexual maturity of swordfish (Xiphias gladius L.) in the waters of Taiwan. Zoological Studies 42 (4): 529-539.

Wootton R.J. 1982. Environmental factors in fish reproduction. Pp. 210-219. In: Richter C.J.J., Goos H.J. (eds.) Proceedings of the international symposium on reproductive physiology of fish. Pudoc Press, Wageningen, the Netherlands.

Wootton R.J. 1984. Introduction strategies and tactics in fish reproduction. Pp. 1-12. In: Potts G.W., Wootton R.J. (eds.) Fish reproduction: Strategies and tactics. Academic Press. London.

Zaki M.I., Hamza A.K. 1986. Reproductive biology and induced spawning of Solea solea (L.) in Egypt. Bulletin of the National Institute, Oceanography and Fisheries (Egypt) 12: 115-125.

Received: 30 September 2017 Accepted: 19 March 2018 Published electronically: 31 March 2018 